\title{
Co-creating Value in the Dyadic Relationships of Small and Large Firms in the Agri- food sector
}

\begin{abstract}
Given the increasing interest in the process of how value is co-created through interaction in business relationships, this paper examines the areas of collaboration, value co-creation practices and the respective co-created value in the dyadic relationships.
\end{abstract}

Multiple case studies design involving in-depth interviews were undertaken with Small and Medium-sized suppliers (SMEs) of organic food in South West England with the dyadic relationship being the unit of analysis.

The findings suggest that SME suppliers and their larger customers collaborate in many areas including: innovation, corporate social responsibility, planning and interactive learning. The collaboration led to co-creation of monetary and nonmonetary values.

This research advances the extant literature on value co-creation in business relationships by examining this complex phenomenon in the context of small and large firms' dyads in the organic food sector. It is novel in identifying the linkage of the co-created value to the respective value co-creation practices and collaborative areas.

Key words: Value co-creation, Dyadic relationships, SMEs, agri-food, Marketing 


\section{Introduction}

As the distinction in the roles of suppliers and customers in production and other activities become blurred (Ford et al., 2006; Sheth and Parvatiyar, 1995; Prahalad and Ramaswamy, 2004b), concomitantly there is increasing interest to understand the process of how value is co-created through interaction in business relationships (Eggert et al., 2018; Forsström, 2005; Ulaga and Eggert, 2006; Okdinawati et al., 2017). In business relationships, the interactions with reference to value co-creation occur largely at areas of collaboration and these in vertical relationships are between customers and their suppliers. Although for the purposes of investigation a researcher could focus on customer-supplier relationships, but it is worth noting that the co-creation of value may involve other actors such as partners, making it a complex adaptive process (Polese et al., 2017).

Most previous studies on value tended to assume one party autonomously creating value for the other, thereby taking only one perspective such as supplier's (e.g. Walter et al., 2001) or customer's (e.g. Ulaga and Eggert, 2006) and hence assuming value creation rather than value co-creation. Other studies are not empirical (e.g. Ulaga, 2001; Bititci et al., 2004; Prahalad and Ramaswamy, 2004a; Vargo et al., 2008) in their analysis of how cooperative interactions in a relationship yield value. Likewise, studies that have attempted to investigate the collaborative areas fail to identify the associated value and how it is co-created (Johnsen and Ford, 2006). Other studies have used nomothetic research design (Eng, 2005; Eng, 2007) which while useful for 
instance in discovery of correlations, tend not to emphasize the process of interplay between contextual and organizational or dyad characteristics.

The extant literature therefore suggests relatively little about how customers engage with suppliers in the co-creation of value. The need to understand how firms co-create value in business relationships has been a call by many researchers (Forsström 2005; Ulaga and Eggert, 2006; Payne et al., 2009). Likewise Terpend et al. (2008) highlight the need for research that would provide more insights into the actual practices and mutual efforts by customers and suppliers for purposes of value generation.

Considering these gaps and in the context of larger customers and small and mediumsized suppliers' (SMEs) dyad, this study identifies the areas of collaboration, how value is co-created and the respective co-created value. The analysis is based on case studies drawn from the UK organic food sector. Organic production takes care of environment and it's guided by set minimum requirements, obliging collaboration among stakeholders to effectively manage the risks involved in maintaining the status of organics as well as to increase benefits (Kottila and Ronni, 2008). Specifically, this paper has four main objectives. Firstly, identify areas of collaboration between larger customers and their SME organic food suppliers. Secondly, identify the value that is associated with the respective collaborative areas. Thirdly, investigate how value is co-created in the focal dyad of larger customers and their SME organic food suppliers. This involves identification of value co-creation practices. Fourthly, identify the theoretical and practical implications of understanding value co-creation in the relationships of larger customers and SME suppliers. 


\section{Background Theory}

Types of value

There are many types of value, comprising of monetary as well as non-monetary value. Monetary value include; volume of sales (Möller and Törrönen, 2003), price premiums (Chernatony et al., 2000) and higher economic returns or profits (Susan and Gibbs, 1995; Reicheld, 1996; Cannon and Homburg, 2001; Spekman and Carraway, 2005; Doole and Lowe, 2008 p.339). On the other hand, non-monetary value includes social satisfactions (Dwyer et al., 1987; Kingshott, 2006), competences (Beugelsdijk et al., 2006; Dyer and Hatch, 2006), symbolic value (Bhat and Reddy, 1998; Bititci et al., 2004) and experiential value (Srivastava et al., 2001). These types are in line with Forsström (2005 p.39) who noted the different types of value in business relationships as comprising of competence related value, reputation related value (for example brand and reference), value related to long-term security, different monetary value, social value, value related to logistics or organizational architecture, and other types of value.

\section{Value creation and co-creation}

Traditional studies on value assumed suppliers and customers acting independently in the creation and consumption of value and thereby characterized by distinct roles of production and consumption respectively. On the contrary, customers and suppliers are increasingly working collaboratively or collectively. Therefore, the parties are not generating value autonomously (value creation) but instead, they are both contributors to this process and are actively involved (value co-creation). Hence, rather than treating the customer as exogenous, similar to Lusch and Vargo (2006), this paper 
consider both parties as endogenous to the value creating activities and processes. Customers are particularly considered to be co-creators of value because they mobilize knowledge and other resources that influence for example the success of a value proposition (Ordanini and Pasini, 2008). In this regard, the collaborative areas by customers and suppliers reflect the potential for value co-creation. Collaboration allows access and utilization of resources not owned or fully controlled by a particular firm and hence contrasts the traditional resource-based view (Barney, 1991). The collaborative areas could include product design (Agndal and Nilsson, 2009), information system links (Day, 1994; Dyer and Singh, 1998), planning (Harvey and Speier, 2000; Johnsen and Ford, 2006; Ngugi et al., 2010), and bilateral development of knowledge and skills (Nahapiet and Ghoshal, 1998; Johnsen and Ford, 2006; Ngugi et al., 2010). The value associated with these areas is however not well understood neither is it clear whether these are the only extant collaborative areas, thus the relevance of this study.

\section{Conceptual framework}

In line with co-creation view, this study focuses on value within a business relationship or in dyadic context rather than outside the relationship (firm-centric). Given the centre of attention in larger customer-SME supplier dyad, then in essence inter-organizational theories become relevant in grounding the work. Interorganizational theories focus on activities and processes that go on between organizations. They recognize that, organizational boundaries (for example in time, place and transactions) become blurred as companies in relationship increasingly share activities such as joint planning, co-production, co-marketing, co-branding and so on (Sheth and Parvatiyar, 1995; Ford et al., 2006 p.206). The focus of this study on 
dyadic relationships means that network theory, better suited for the wider network, may not be hereby adopted. Therefore, the IMP interaction approach (Hakansson, 1982), suited at least for investigations in a single relationship, is herewith adopted. Interaction recognizes that firms are interdependent with the other in the relationship (Ford et al., 2006 p.46). The IMP approach has the advantage at least in its ability to combine views from both business marketing and business purchasing. It addition, it is characterized by strength in its face validity, its strong theoretical basis, and its extensive empirical testing using case studies of over a thousand buyer-supplier relationships (Olsen and Ellram, 1997). Indeed, the approach is considered the best equipped theoretical framework to deal with the various issues pertaining to buyerseller relationships (Wilson and Mummalaneni, 1986; Metcalf et al., 1992).

Moreover, the interaction approach establishes some of the inherent characteristics of customer-supplier relationships in business relationships including the assumptions that (Hakansson, 1982; Ford, 2002 p.22): (a) buyer and seller are active participants in the market (b) the relationship between buyer and seller are frequently long term, close, and involve a complex pattern of interaction between and within each company (c) the links between buyer and seller often become institutionalized into a set of roles that each party expects the other to perform (d) close relationships are often considered in the context of continuous raw material or components supply.

In accordance with the IMP interaction approach, this research assume that since at least two active parties are involved (herewith a larger customer and SME supplier) collaboratively in the interaction process, then it's not one party that is creating value 
alone for the other but rather both parties are actively involved. Accordingly, similar to other studies (e.g. Forsström, 2005; Lefaix-Durand, 2008), this research adopt the term value co-creation rather than value creation to imply that both parties are involved collaboratively as opposed to one party independently. The beneficial outcomes from the value co-creation process are most likely to be to all the collaborating parties though there is also a possibility that this may be limited to a few or singe firm. The collaboration rules out opportunism behavior and therefore its contrary to transaction costs theory (Williamson, 1979). The conceptual framework, figure 1 , is assumed in the investigation of the value co-creation phenomenon. It links the themes of: customer-supplier interaction, collaboration and hence value cocreation, and the co-created value. This at least allows for examination of the customer-supplier relationships along the dimensions of processes and outcomes (Holmlund, 2004). 
Figure 1: A conceptual framework to examine value co-creation in the larger customer-SME supplier's dyad

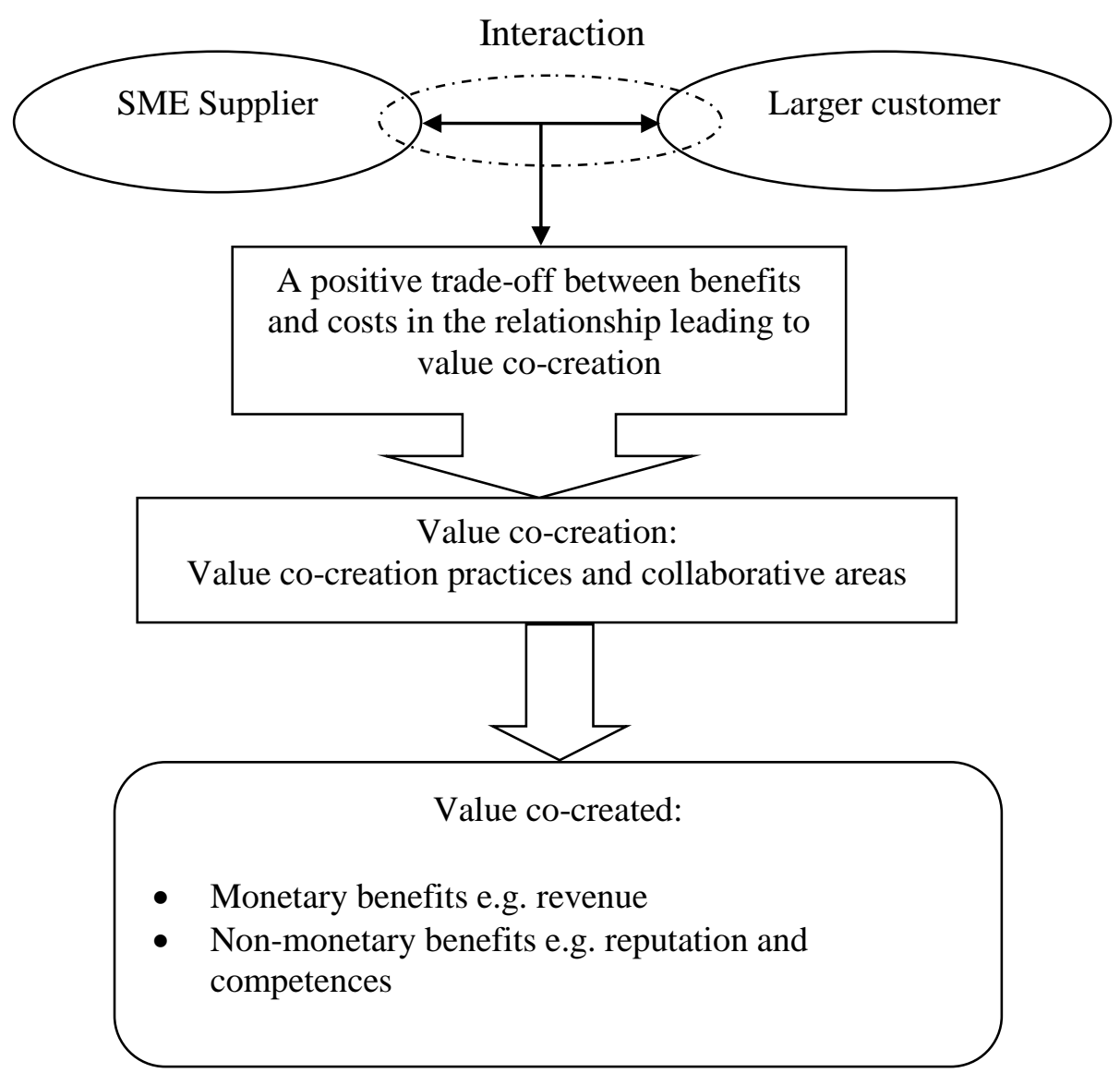

The framework is developed on the basis that value is co-created jointly and reciprocally in interactions among providers and beneficiaries through the integration of resources and application of competences. This is consistent with other authors (Ford et al., 2006 p.46; Vargo et al., 2008). Through value co-creation processes in business-to-business relationships, resources of the companies involved are combined thereby enabling them to achieve something that one of the parties could not achieve alone (Freiling, 2004). In a nutshell, figure 1 assumes that it is rational for larger customers and SME suppliers to interact in order to create something together for 
instance through use of each other's resources. They are compelled to collaborate if they perceive this as beneficial. Interaction implies that neither party is passive nor independent but rather both parties are active and interdependent and act collaboratively. Value is co-created through the collaborative areas. This study's main focus is on structural dimension (e.g. ties, links and connections) rather than for instance social dimension (e.g. commitment, trust and atmosphere) of business relationships (Holmlund and Törnroos, 1997). The value co-creation practices in the collaborative areas represents how value is co-created and the co-created value include both monetary and non-monetary.

\section{Methodology}

The study area is South West region of England. This is the largest agricultural region in England and it is characterised by mild climate which allow a prolonged growing and rearing season (SouthWest-RDA, 2007). In the organic food sector, the region is the strongest in England accounting for 26 per cent of all organic farmers (ibid). The region has many small and medium sized agribusinesses (SME suppliers) as well as large supermarkets (large customers) and this makes it appropriate for this study, given the focus on relationships between small and large firms.

The paper adopts a qualitative approach involving multiple case study design (Yin, 2009). Three exploratory in-depth case studies were conducted. The selection criteria were based on the small-medium size of the suppliers, their focus on organic food production and their involvement with large retail customers. Managing Directors were selected as the key respondents within the SMEs because of their knowledge and experience and close involvement in relationships with larger customers. The in-depth interviews were recorded and transcribed. The transcripts were annotated and classified into meaningful themes and categories using Nvivo software. These were 
later cross-checked with the transcripts and also the draft findings were reviewed by key informants as a means of validation.

\section{Findings}

For ethical reasons, the names of the SME suppliers and their larger-customers have been made anonymous. Based on the number of employees, the interviewed suppliers were smaller than the customers. As shown in Table 1, the suppliers ranged from micro enterprise (five employees) to medium sized (115 employees) (Commission of European Communities, 2003). The names Sowa, Chesa and Bete are adopted for the suppliers and Alpha, Omega and Zeta for their larger customers respectively, rather than the real names of the companies that participated in the study.

Table 1: Description of SME Suppliers

\begin{tabular}{llll}
\hline Attribute & Chesa & Sowa & Bete \\
\hline Company size & Medium & Small & Micro \\
Annual Turnover & $£ 20 \mathrm{~m}$ & $£ 1 \mathrm{~m}$ & $£ 60000$ \\
Balance sheet total & $£ 9 \mathrm{~m}$ & Declined to reveal & $£ 12000$ \\
No. of employees & 115 & 18 & 5 \\
Main products & Cheese & Soups and sauces & Beef \\
\hline
\end{tabular}

Table 2 summarizes the findings, comprising of; areas of collaboration, value cocreation practices, the value co-created, and the respective case study relationships in which the value co-creation occurred. 
Table 2: Findings on areas of collaboration, value co-creation practices and the value co-created

\begin{tabular}{|c|c|c|c|}
\hline $\begin{array}{l}\text { Areas of } \\
\text { collaboration }\end{array}$ & $\begin{array}{l}\text { Value co-creation } \\
\text { practices }\end{array}$ & $\begin{array}{l}\text { Value } \\
\text { co-created }\end{array}$ & $\begin{array}{l}\text { Larger customer - } \\
\text { SME supplier } \\
\text { relationship }\end{array}$ \\
\hline \multirow[t]{2}{*}{ Innovation } & $\begin{array}{l}\text { Consultations and exchange of } \\
\text { ideas on product development, } \\
\text { name and packaging }\end{array}$ & $\begin{array}{l}\text { Increased ranges of } \\
\text { successful products: } \\
\text { interesting to consumers }\end{array}$ & Alpha-Sowa \\
\hline & $\begin{array}{l}\text { Recommending development of } \\
\text { very small cheese to fit children's } \\
\text { lunch packs }\end{array}$ & Increased revenues & Omega-Chesa \\
\hline $\begin{array}{l}\text { Corporate Social } \\
\text { Responsibility (CSR) }\end{array}$ & $\begin{array}{l}\text { Collaboration in exposing school } \\
\text { children to agricultural aspects } \\
\text { though facilitating and } \\
\text { sponsoring farm visits }\end{array}$ & $\begin{array}{l}\text { Reputation/public } \\
\text { relations }\end{array}$ & Omega-Chesa \\
\hline \multirow[t]{2}{*}{$\begin{array}{l}\text { Interlinked technical } \\
\text { system: Electronic data } \\
\text { interchange (EDI) }\end{array}$} & $\begin{array}{l}\text { Collaboration in establishment } \\
\text { and utilization of electronic data } \\
\text { interchange }\end{array}$ & $\begin{array}{l}\text { Higher sales for both } \\
\text { firms }\end{array}$ & Omega-Chesa \\
\hline & & $\begin{array}{l}\text { Continuous supply: no } \\
\text { empty shelves }\end{array}$ & Omega-Chesa \\
\hline \multirow[t]{3}{*}{$\begin{array}{l}\text { Co-planning: Business } \\
\text { plan development }\end{array}$} & $\begin{array}{l}\text { Development of business plan } \\
\text { through several iterations in } \\
\text { consultation with both customer's }\end{array}$ & $\begin{array}{l}\text { Continuous supply in } \\
\text { appropriate quantities }\end{array}$ & Omega-Chesa \\
\hline & and supplier's staft & $\begin{array}{l}\text { Increased sales through } \\
\text { promotional products } \\
\text { agreed during co- } \\
\text { planning }\end{array}$ & Omega-Chesa \\
\hline & & Guaranteed cashflows & Omega-Chesa \\
\hline \multirow{2}{*}{$\begin{array}{l}\text { Co-evaluation \& } \\
\text { development of } \\
\text { training needs }\end{array}$} & $\begin{array}{l}\text { Supermarket \& SME Directors } \\
\text { together evaluate factory and }\end{array}$ & Improved quality & Alpha-Sowa \\
\hline & staff and identify training needs & Preferred supplier status & Alpha-Sowa \\
\hline \multirow[t]{4}{*}{ Interactive learning } & \multirow[t]{2}{*}{$\begin{array}{l}\text { Supplier's staff with support } \\
\text { from the customer help at } \\
\text { customer's premises for example } \\
\text { in stacking shelves }\end{array}$} & $\begin{array}{l}\text { Enhanced understanding } \\
\text { of consumer needs and } \\
\text { desires }\end{array}$ & Omega-Chesa \\
\hline & & Enhanced innovation & Omega-Chesa \\
\hline & \multirow{2}{*}{$\begin{array}{l}\text { Supplier's staff sensitized on } \\
\text { quality issues at customer's } \\
\text { premises. }\end{array}$} & Improved quality & Zeta-Bete \\
\hline & & $\begin{array}{l}\text { Enhanced understanding } \\
\text { of customer's needs }\end{array}$ & Zeta-Bete \\
\hline
\end{tabular}


The findings (Table 2) indicate a number of areas in which SME suppliers collaborated with their larger customers. Working in collaboration on activities such as; product innovations, co-participation in social responsibility activities, joint technical systems, joint planning, joint recognition and development of training needs, developing suppliers to achieve preferred supplier status and interactive learning were key elements of value co-creation.

The value co-creation practices, signifying how value was actually co-created, are also shown in Table 2 and they included: exchanging ideas on product development core products as well as name and packaging; facilitating and sponsoring visits to farms by school children; setting up and sustaining electronic data interchange; consultations in development of business plan, co-evaluating processes and staff; and internships.

According to the findings, the value co-created comprised both monetary such as increased sales and revenue and non-monetary such as reputation, preferred supplier status and improved quality. Some value co-creation aspects (such as EDI which enhanced continuous supply) enhanced efficiency and effectiveness in the exchange process thereby directly contributing largely to monetary benefits such as revenue generation while others (for instance corporate social responsibility) contributed largely to non-monetary benefits such as favorable reputation or publicity. This findings are consistent with previous studies which acknowledge the generation of both monetary and non-monetary value in business relationships (Forsström, 2005; 
Ulaga and Eggert, 2006; Ngugi et al., 2010). Though not limited to customersupplier relationships, Okdinawati et al. (2017) finds that the nature and extent of collaboration amongst the applicable agents in the transport sector influences the transportation cost, visibility, and agility - hence impacting on both monetary and non-monetary value. This study builds on such literature by further identifying the specific monetary or non-monetary value that was co-created in the respective collaborative areas and relationships of larger customers and their SME suppliers (Table 2).

It is interesting to note that some collaborative areas led to co-creation of more types of value than others. For instance collaboration in interactive learning promoted cocreation of four types of value (enhanced understanding of larger customer's needs, enhanced understanding of consumers' needs and desires, enhanced innovation, and improved quality) while collaboration in corporate social responsibility activities was found to lead to co-creation of one type of value - public relations. Also, some different collaborative areas were found to lead to co-creation of same type of value. For instance collaboration in business plan development and interlinked systems such electronic data interchange were both identified as contributing to promotion of continuous supply of products. The findings on the collaborative areas, value cocreations practices and the corresponding outcomes in terms of the co-created value, has ramifications in resource allocation. That is, if the management's priority is to achieve particular outcome (s), they would be expected to invest in the appropriate collaborative area (s).

\section{Innovation}


The findings of this research show collaboration as enhancing innovativeness of the collaborating firms especially in terms of increasing the ranges of new successful products. This is consistent with Nieto and Santamaría (2010) who find that technological collaboration is a useful mechanism for firms of all sizes to improve innovativeness and a critical factor for the smallest firms. The success of the larger customer-SME supplier relationship is particularly essential considering that one of the factors that contribute to low innovative performance of small firms compared to large firms is lack of external partners (Hewitt-Dundas, 2006; Madrid-Guijarro et al., 2009). In this study, the collaboration, for instance in innovation, was characterized by involvement of employees of both firms as well as open communication amongst them. These (open communication and high employee involvement) are characteristics of market oriented organizations (Martin et al., 2009) and such orientation is considered vital in achievement of superior competitive performance especially by mainstream customers (Zhou et al., 2005).

\section{Corporate social responsibility}

Although corporate social responsibility activities are usually associated with large firms, this study found participation of SMEs as well. This is demonstrated in the Omega-Chesa relationship through the practice of sponsoring school children to visit farms. This signifies the power of business relationships in promoting SMEs' participation in social responsibility activities. The participation or the increasing interest in such activities is in line with the growth of large companies' reporting on corporate social responsibility (Stern and Ander, 2008).

\section{Interlinked technical systems}


Collaboration in the establishment and utilization of electronic data interchange was useful in enhancing continuous supply leading to mutual increase in sales. Such a computerized communication system is also likely to make it easier for customers to interact with suppliers (Sheth and Parvatiyar, 1995) for instance in relation to order status and payment information (Day, 2000). The connection of suppliers with customers has been identified by other works (Day, 2000; Randall, 2001). The linking of computer systems builds structural bonds that are difficult and expensive to break for instance because an incumbent relationship partner has inertia helping to maintain the relationship and as long as the incumbent continues to deliver value it will be difficult for a new supplier to break the relationship (Kothandaraman and Wilson (2001).

\section{Co-planning}

Planning together by suppliers and customers is becoming an increasing phenomenon (Johnsen and Ford, 2006; Ngugi et al., 2010). In this study, collaborative planning is seen in form of development of business plans through several iterations in consultation with both customer's and supplier's staff, though could also involve joint development of supplier's and customer's structures, strategies and relationships (Johnsen and Ford, 2006). The overall strategic alignment of similar goals and objectives of customers and suppliers is crucial to develop the value from the relationship (Barber, 2008) and it significantly influences the achievement of strategically-oriented goals (Ling-yee and Ogunmokun, 2001).

\section{Co-evaluation}

Customers and suppliers in the study were found to be involved in co-evaluation and identification of training needs. This meant that both the supplier and customer's 
needs were considered and planned for in advance. For example, in the Alpha-Sowa relationship, the supermarket (larger customer) in collaboration with the small supplier's directors evaluated the factory and staff. The supplier's directors were thus not being evaluated by the larger customer but were included in a process of coevaluation. During the process, Sowa and its larger customer together identified gaps that the smaller supplier needed to fill or work on to sustain its position as a preferred supplier, such as the need for upgrading and maintaining hygiene and safety skills.

\section{Interactive learning}

The findings also show the SME suppliers collaborating with their larger customers in supporting interactive learning. Knowledge gained through interactive learning between two firms is more likely to permit a firm to add unique value to its own capabilities compared to that gained through passive or active learning which provide articulable (observable) knowledge and hence not rare, imperfectly traded or costly to imitate (Lane and Lubatkin, 1998). Collaboration in learning is reported by other studies (Johnsen and Ford, 2006; Ngugi et al., 2010). This involves combinations of knowledge and this particularly when combined with input from the larger customer has been found to lead to knowledge creation (Tolstoy, 2009). Mutual learning signifies existence of reciprocal interdependence in the relationship (Borys and Jemison, 1989; Hammervoll, 2009). Therefore, in addition to sequential interdependence which typically characterizes customer-supplier relationships (ibid), the findings of this study show that there is learning and adaptations in larger customer-SME supplier relationships. 
Considering the wide range of ways into which value was co-created, this research argue that, although the collaborative areas may likely be common across customersuppliers relationships, the value co-creation practices or rather how value is actually co-created would likely vary across relationships. This is also expected to vary depending on the sector under consideration. For instance, while collaborative innovation may be common in organic sector as well as in other sectors, the specific innovation practice such as development of unique cheese is specific to food industry but this clearly would be different in a non-food industry. In addition, the findings of this study (Table 2) show the relationship with the smallest supplier, Zeta, being characterized by the fewest number of collaborative areas and value co-creation practices. This suggests that size of a supplier may be an influencing factor in value co-creation processes.

\section{Implications}

This study has contributed to better understanding of how customers and suppliers in relationships co-create value. It has identified the areas of collaboration, described how value is co-created and identified the co-created values in the larger customerSME supplier dyadic relationships.

\section{Managerial implications}

It is vital that managers in SME suppliers are able to assess those activities that must be done internally or developed in conjunction with larger customers. The findings underscore the issue of the survival and prosperity of SME suppliers being closely linked to effective collaboration with their larger customers, in addition to their internal success (Hakansson and Ford, 2002). The power of business relationships in enhancing combination and access to skills, resources and technologies of both the collaborating firms and in contributing towards problem solving for both the customer 
and the supplier is revealed. The identified interactive learning and collaborative innovation implies that firms may need to work collaboratively for instance through project groups or internships whereby representatives from both firms in relationship can interact or meet and communicate their business operations and ideas and consequently co-create value.

The findings suggest the potential of some collaborative areas leading to co-creation of more types of value than others. Also, some different areas were found to contribute to co-creation of the same type of value. Such knowledge (collaborative areas and respective types and amounts of value) would be useful to managers in guiding decision-making particularly in relation to collaborative areas with larger customers. Relationships entail investments and therefore the understanding of the value co-created through the various collaborative areas and value co-creation practices would be useful in deciding which areas would be best to collaborate and hence invest. Whilst making decisions on relationship investments, it is also important to bear in mind that the outcomes or the co-created value may not always be linear (Luu et al., 2018).

\section{Theoretical implications}

The findings demonstrate that the interaction process in business relationships involves more than just exchange since it also involves value co-creation. The value co-creation occurs at areas of collaboration and the collaborating parties are able to come up or do something that they would not usually do alone. This aspect of cocreating in addition to exchange suggests the need to modify or improve the IMP interaction framework (Hakansson, 1982) by entrenching the concept of value cocreation into it. 
The findings also support the increasingly observed phenomenon of collaboration among firms as opposed to the traditional strategies of autonomous competition. This shows that firms are increasingly realizing that there is more to gain by collaborating than operating individually. Lastly, unlike traditionally where the objective of firms tended to be solely financial, this study has shown that firms are now recognizing non-financial aspects as important value that is co-created in business relationships. In any case, the identified different types of monetary and non-monetary value are relevant to academia especially those interested in understanding the emerging new ways in which value is co-created and thus new definition of value.

\section{Limitations and areas for further research}

The data were collected from SME suppliers only, which means that there is scope for incorporating data from larger customer. The findings are based on three case studies, which suggest the need for extending this to saturation. Also, the data used here is largely cross-sectional and therefore covering longer span of time and adoption of other approaches such as ethnography would likely generate useful information. Furthermore, future studies could go beyond the dyadic relationships to include perspectives from the wider network. In addition, further research which goes beyond one industry and one country may be essential in enabling extrapolation and generalization into other situations than those investigated in this study. Nonetheless, this study is fundamental in that it is among the first to investigate the co-creation of value in larger customer-SME supplier relationships in the organic food sector. 


\section{References}

Agndal, H. and Nilsson U. (2009). Interorganizational cost management in the exchange process. Management Accounting Research, 20(2), 85-101.

Barber, E. (2008). How to measure the "value" in value chains. International Journal of Physical Distribution \& Logistics Management, 38(9), 685-698.

Barney, J. B. (1991). Firm resources and sustained competitive advantage. Journal of Management, 17, 99-120.

Beugelsdijk, S., Koen C. I. and Noorderhaven N.G. (2006). Organizational culture and relationship skills. Organization Studies, 27(6), 833-854.

Bhat, S. and Reddy S. K. (1998). Symbolic and functional positioning of brands. Journal of consumer marketing, 15(1), 32-43.

Bititci, U. S., Martinez V., Albores P. and Joniarto P. (2004). Creating and managing value in collaborative networks. International Journal of Physical Distribution and Logistics Management, 34(3/4), 251-268.

Borys, B., and Jemison D. B. (1989). Hybrid arrangements as strategic alliances: theoretical issues in organizational combinations, Academy of Management Review, 14, 234-49.

Cannon, J. P., and Homburg C. (2001). Buyer-supplier relationships and customer firm costs. Journal of Marketing, 65(1), 29-43.

Chernatony, L. d., Harris F. and Riley F.D. (2000). Added value: its nature, roles and sustainability. European Journal of Marketing, 34(1/2), 39-56.

Commission of European Communities (2003). Commission recommendation of 06/05/2003 concerning the definition of micro, small and medium-sized enterprises. Brussels.

Day, G.S. (1994). The capabilities of market-driven organizations. Journal of Marketing, 58(4), 37-52.

Day, G. (2000). Managing market relationships. Journal of the Academy of Marketing Science, 28(1), 24-30.

Doole, I. and Lowe R. (2008). International marketing strategy: analysis, development and implementation. London, Cengage Learning EMEA.

Dwyer, F., Schurr P. and Oh S. (1987). Developing buyer-seller relationships. Journal of Marketing, 51, 11-27.

Dyer, J. H. and Hatch N. W. (2006). Relation-specific capabilities and barriers to knowledge transfers: creating advantage through network relationships. Strategic Management Journal, 27(8), 701-719.

Dyer, J. H., and Singh H. (1998). The relational view: cooperative strategy and sources of interorganizational competitive advantage. Academy of Management Review, 23 (4), 660-679.

Eggert, A. , Ulaga W., Frow P. and Payne A. (2018). Conceptualizing and communicating value in business markets: From value in exchange to value in use. Industrial Marketing Management. 69 (February 2018), 80 90.

Eng, T.-Y. (2005). The effects of learning on relationship value in a business network context. Journal of Business-to-Business Marketing, 12(4), 67-101.

Eng, T.-Y. (2007). Relation value of firms in alliance capitalism and implications for FDI. International Journal of Business Studies, 15 (1), 43-68.

Ford, D. (2002). Understanding business marketing and purchasing. London, Thomson learning.

Ford, D., Gadde L., Hakansson H. and Snehota I. (2006). The business marketing course: managing in complex networks. England, John Wiley and Sons Ltd. 
Ford, D., and. McDowell R (1999). Managing Business Relationships by Analyzing the Effects and Value of Different Actions. Industrial Marketing Management, 28(5), 429-442.

Forsström, B. (2005). Value co-creation in industrial seller partnerships - creating and exploiting interdependencies. $\AA B O A K A D E M I S$ FÖRLAG - $А B O A K A D E M I$ UNIVERSITY PRESS, ABO AKADEMIS FÖRLAG - ÅBO AKADEMI UNIVERSITY PRESS.

Freiling, J. (2004). A Competence-based theory of the firm. Management Revue, 15(1), 27-52.

Hakansson, H., Ed. (1982). International marketing and purchasing of industrial goods. Chichester, John Wiley and Son.

Hakansson, H. and Ford D. (2002). How should companies interact in business networks? Journal of Business Research, 55, 133-139.

Hammervoll, T. (2009). Value-creation logic in supply chain relationships. Journal of Business-to-Business Marketing, 16 (3), 220-41.

Harvey, M. and Speier C. (2000). Developing an inter-organization relational management perspective. Journal of Marketing Channels, 7(4), 23-44.

Hewitt-Dundas, N. (2006). Small business economics. Resource and Capability Constraints to Innovation in Small and Large Plants, 26, 257-277.

Holmlund, M. (2004). Analyzing business relationships and distinguishing different interaction levels. Industrial Marketing Management, 33 (4), 279-287.

Holmlund, M. and Törnroos J. Å. (1997). What are relationships in business networks? Management decision, 35 (4), 304.

Johnsen, R. E. and Ford D. (2006). Interaction capability development of smaller suppliers in relationships with larger customers. Industrial Marketing Management, 35(8), 1002-1015.

Kingshott, R. P. J. (2006). The impact of psychological contracts upon trust and commitment within supplier-buyer relationships: A social exchange view. Industrial Marketing Management, 35(6), 724-739.

Kothandaraman, P. and Wilson D. T. (2001). The future of competition: valuecreating networks. Industrial Marketing Management, 30(4), 379-389.

Kottila, M.R. and Ronni P. (2008). Collaboration and trust in two organic food chains. British Food Journal, 110 (4/5 ), 376 - 394.

Lefaix-Durand, A. (2008). Customer-supplier relationships as a means of value creation, PhD thesis, MANAGEMENT SCIENCES DE

L'ADMINISTRATION UNIVERSITÉ LAVAL QUÉBEC.

Ling-yee, L. and Ogunmokun G. O. (2001). The influence of inter-firm relational capabilities on export advantage and performance: an empirical analysis. International Business Review, 10(4), 399-420.

Lusch, R. F. and Vargo S. L. (2006). Service-dominant logic: reactions, reflections and refinements. Marketing Theory, 6(3), 281-288.

Luu, N., Ngo L.V. and Cadeaux J.(2018). Value synergy and value asymmetry in relationship marketing programs. Industrial Marketing Management, 68(January 2018), 165-176.

Madrid-Guijarro, A., Garcia D. and Auken H.V. (2009). Barriers to innovation among Spanish manufacturing SMEs. Journal of Small Business Management, 47(4), 465-488.

Martin, J. H., Martin B. A. and Minnillo P.R. (2009). Implementing a market orientation in small manufacturing firms: from cognitive model to action. Journal of Small Business Management, 47(1), 92-115. 
Metcalf, L.E., Frear C. R. and Krishnan R. (1992). Buyer-seller relationships: an application of the IMP interaction model. European Journal of Marketing, 26(2), 27-46.

Möller, K. E. K. and Törönen P. (2003). Business suppliers' value creation potential: A capability-based analysis. Industrial Marketing Management, 32(2), 109118.

Nahapiet, J. and Ghoshal S. (1998). Social capital, intellectual capital, and the organizational advantage. The Academy of Management Review, 23(2), 242266.

Ngugi, I. K., Johnsen E. R. and Erdélyi P. (2010). Relational capabilities for value cocreation and innovation in SMEs. Journal of Small Business and Enterprise Development, 17 (2), 260-278.

Nieto, M. J. and Santamaría L. (2010). Technological collaboration: bridging the innovation gap between small and large firms. Journal of Small Business Management, 48(1), 44-69.

Olsen, R. F. and Ellram L. M. (1997). Buyer-supplier relationships: alternative research approaches. European Journal of Purchasing \& Supply Management, 3(4), 221-231.

Ordanini, A. and Pasini P. (2008). Service co-production and value co-creation: The case for a service-oriented architecture (SOA). European Management Journal, 26(5), 289-297.

Payne, A., Storbacka K., Frow P. and Knox S. (2009). Co-creating brands: Diagnosing and designing the relationship experience. Journal of Business Research, 62(3), 379-389.

Polese, F. Mele C. and Gummesson E. (2017). Value co-creation as a complex adaptive process. Journal of Service Theory and Practice, 27(5), 926-929, https://doi.org/10.1108/JSTP-07-2017-0111

Prahalad, C. and Ramaswamy V. (2004a). Co-creating unique value with customers. Strategic management journal, 32(3), 4-9.

Prahalad, C. K. and Ramaswamy V. (2004). The future of competition: co-creating unique value with customers. Boston, Massachusetts, Harvard Business School

Prahalad, C. K. and Ramaswamy V. (2004b). Co-creation experiences: The next practice in value creation. Journal of Interactive Marketing, 18(3), 5-14.

Randall, G. (2001). Principles of marketing. London, Thomson Learning

Reicheld, F. (1996). The loyalty effect. Cambridge, MA, Harvard Business School Press.

Sheth, J. N. and Parvatiyar A. (1995). The evolution of relationship marketing. International Business Review, 4(4), 397-418.

SouthWest-RDA (2007). Key industries: food and drink, South West Regional Development Agency

Spekman, R. and Carraway R. (2005). Making the transition to collaborative buyerseller relationships: an emerging framework. Industrial Marketing Management, 35, 10-19.

Srivastava, R. K., Fahey L. and Christensen H.K. (2001). The resource-based view and marketing: The role of market-based assets in gaining competitive advantage. Journal of Management, 27(6), 777-802.

Stern, N. Z. and Ander W. N. (2008). Greentailing and other revolutions in retail: hot ideas that are grabbing customers' attention and raising profits. New Jersey, John Wiley \& Sons, Inc. 
Susan, A. and Gibbs J. (1995). Retailer-supplier relationships and the evolution of marketing: two food industry case studies. International Journal of Retail \& Distribution Management, 23(7), 7 - 16.

Terpend, R., Tyler, B.B., Krause, D.R., and Handfield R.B. (2008). Buyer-supplier relationships: derived value over two decades. Journal of Supply Chain Management, 44 (2), 28-55.

Tolstoy, D. (2009). Knowledge combination and knowledge creation in a foreignmarket network. Journal of Small Business Management, 47(2), 202-220.

Ulaga, W. (2001). Customer Value in business markets: an agenda for inquiry. Industrial Marketing Management, 30(4), 315-319.

Ulaga, W. and Eggert A. (2006). Value-based differentiation in business relationships: gaining and sustaining key supplier status. Journal of Marketing, 70(1), 119136.

Vargo, S. L., Maglio P. P. and Akaka M.A. (2008). On value and value co-creation: A service systems and service logic perspective. European Management Journal, 26: $145-152$.

Walter, A., Ritter T. and Gemünden H.G. (2001). Value creation in buyer-seller relationships: theoretical considerations and empirical results from a supplier's perspective. Industrial Marketing Management, 30(4), 365-377.

Williamson, O. E. (1979). Transaction-Cost Economics: The governance of contractual relations. The Journal of Law and Economics, 233-260.

Wilson, D. T. and Mummalaneni V. (1986). Bonding and commitment in buyerselller relationships: a preliminary conceptualization. Industrial marketing and purchasing 1(3), 44-58.

Yin, R. K. (2009). Case study research - design and methods. 4th edition. London, SAGE publications.

Zhou, K., Yim C. and Tse D. (2005). The effects of strategic orientations on technology- and market-based breakthrough innovations. Journal of Marketing, 69(2), 42-60. 